\title{
Kerjasama Institusi Pendidikan Tinggi Dan Pemerintah Daerah Dalam Mengatasi Kenakalan Remaja Di Sekolah
}

\author{
Rapia Arcanita \\ Institut Agama Islam Negeri (IAIN) Curup \\ rapiaarcanita@gmail.com \\ Guntur Putrajaya \\ Institut Agama Islam Negeri (IAIN) Curup \\ gunturputrajaya@gmail.com
}

\begin{abstract}
This research was done based on 1) increasing a number of juvenile in detention class II a Curup. 2) there was a wish of regional government to realize religius and good character education. 3) most of IAIN Curup students' background are from public school including senior high school in Rejang Lebong regency. Based on those considerations, therefore the researcher tried to reveal how werethe form and model implementation of the shared concept like in the field. The subject of this research are some senior high schools in Rejang Lebong regency using purposive sampling model of Sugiono. From the answer of respondents knowing that religius and character education in senior high school in Rejang Lebong regency had been realized however had not been maximal. It happened because some barrier factors, both from the school (internal) and outside school (external) as described on the first session. Then, the cooperation of higher education (IAIN) and regional government to resolve juvenile delinquency in school had not been maximal actually, because it had not touched the school specifically, it was done only daily routine, such as PPL, KPM, or Friday safari. But, the school desire for IAIN Curup as coach in religious spiritual progress had not been achieved
\end{abstract}

Key words: Education, character, religius, and IAIN Curup

Abstrak: Penelitian ini dilakukan atas dasar 1) meningkatnya penghuni lapas klas II a Curup seusia remaja. 2) adanya keinginan pemerintah daerah untuk mewujudkan sekolah yang religius dan berkarakter baik. 3) sebagaian besar latar belakang mahasiswa IAIN Curup dari sekolah umum termasuk dari SMA yang ada di Kabupaten Rejang Lebong. Atas dasar pertimbangan tersebut, maka peneliti mencoba mengungkap bentuk dan model pelaksanaan gagasan bersama tersebut seperti apa di lapangan. Subjek dalam penelitian ini beberapa sekolah SMA yang ada di Kabupaten Rejang Lebong merujuk pada Sugiono (proposif sampling). Dari jawaban responden diketahui, bahwa pendidikan karakter dan religius di SMA yang ada di Kabupeten Rejang Lebong sudah diterapkan kendatipun belum maksimal. Hal tersebut dikarenakan beberapa faktor penghalang, baik dari pihak sekolah (internal sekolah) maupun dari luar sekolah (eksternal sekolah) sebagai mana telah diuraikan pada pembahasan sebelumnya. Kemudian kerjasama pendidikan tinggi (IAIN) dan 
pemerintah daerah untuk mengatasi kenakalan remaja di sekolah pada dasarnya belum maksimal, karena belum menyentu pihak sekolah secara khusus, adapun yang telah dilakukan sebatas kegiatan rutinitas, seperti PPL, KPM atau safari jumat. Namun keingananan sekolah agar IAIN Curup sebagai Pembina dalam kemajuan spiritual keagamaan belum tercapai.

Kata Kunci: pendidikan, karakter, religius dan IAIN Curup

\section{Pendahuluan}

Pada tahun 2017 Pemda Kabupaten Rejang Lebong melalui beberapa keputusan bupati Rejang Lebong ${ }^{1}$ menetapkan bahwa :

1. Semua sekolah wajib melaksanakan solat zuhur berjamaah di sekolah

2. Hari senin s.d kamis wajib berpakaian panjang baik-laki-laki maupun perempuan yang non Religius menyesuaikan.

3. Jumat wajib memakai pakain busana muslim dan muslimah, yang non Religius menyesuaikan.

4. Selama bulan Ramadhan wajib berbusana muslim.

5. Semua sekolah wajib melaksanakan penerapan pendididkan secara konten dan berkesinambungan

6. Pemerintah daerah merekrut tenaga pengajar / guru ngaji pada setiap kelurahan dan digaji oleh pemerintah daerah.

7. Surat disampaikan kepada Kepala Dinas Pendidikan Kab. Rejang Lebong dengan tembusan seluruh Kecamatan dan kelurahan Kab. Rejang Lebong.

Surat Keputusan dari pemerintah daerah mengenai aturan pada pendidikan (sekolah) tersebut diharapkan dapat mengurangi tingkat kriminalitas pada masyarakat terutama dunia pendidikan (sekolah) baik tingkat dasar, menengah, lanjutan maupun perguruan tinggi. Selain itu pemerintah daerah juga melibatkan perguruan tinggi khususnya IAIN Curup dalam mengurangi tingkat kenakalan remaja. Beberapa kegiatan kerjasama tersebut antara lain:

1. Melalui KPM revolusi mental beberapa waktu yang lalu. Walaupun secara pendanaan KPM-RM berasal dari diktis namun regulasinya diserahkan pada pemerintah setempat.

2. Melalui safari jum'at yang juga diselenggarakan oleh dosen dan karyawan IAIN Curup.

3. Desa binaan dari P3M IAIN Curup, dengan melibatkan dosen untuk menjadi penyuluh agama pada setiap desa.

4. Pengajian-pengajian dari semua unsur instansi pemerintah di Kabupaten Rejang Lebong sangat digalakkan, makanya sekarang guru-guru mengaji di setiap kelurahan di gaji oleh Pemerintah.

\footnotetext{
${ }^{1}$ Surat keputusan ini ditanda tangani oleh Sekda Kabupaten Rejang Lebong yaitu RA. Denny SH, MM pada tanggal 24 Mei 29017 . dapat dilihat di dokumen Pemda bagian Pendidikan.
} 
Usaha pemerintah daerah tersebut sudah mulai berjalan, hanya saja apakah memberikan kontribusi secara signifikan terhadap masyarakat atau belum, inilah yang menjadi fokus dalam penelitian ini nantinya. Hal ini terkait dengan kabupeten Rejang Lebong yang memiliki tingkat kejahatan cukup tinggi, terlihat beberapa kasus kejahatan, antara lain:

1. Kejahatan secara umum

a. Kasus pemerkosaan atau kejahatan seksualitas. Sebagai mana kasus yuyun yang tidak asing lagi. Seorang anak SMP diperkosa oleh para pemuda secara bergilir sebanyak 13 orang. Terjadinya di Kecamatan Padang ulak tanding tepatnya di desa belumai, menyita perhatian masyarakat secara nasional dan tetap membuat terpuruk bagi keluarganya.

b. Penodongan yang masih sering terjadi sampai sekarang di desa Kepala Curup dan sekitarnya, bahkan sudah merenggut banyak nyawa manusia dan menyita perhatian nasional sampai sekarang dan pelakunya sebagian besar anak seusia SMA

c. Narkoba, judi dan kejahatan lainnya, sebagian besar pelakunya adalah anakanak usia produktif sekolah

2. Kejahatan para siswa secara khusus

Dari pengamatan awal penelitian ini, ditemukan beberapa siswa sekolah tingkat SMA sudah melakukan pelanggaran, antara lain:

a. Pencurian

b. Perkelahian

c. Pelecehan seksual (pemerkosaan, berbuat asusila)

d. Kemudian bentuk penynyimpangan seksual yang terkategori pada LGBT. Sebagai mana baru-baru ini unsur muspida berserta dengan para ulama yang ada di Kabupaten rejang Lebong mengadakan musyawarh daerah dalam rangka membahas upaya menangani LGBT.

Peraturan daerah tersebut berawal dari adanya beberapa keinginan pemerintah daerah terhadap masyarakat kabupaten Rejang Lebong yaitu:

\section{Adanya keinginan pemerintah daerah untuk mewujudkan pendidikan karakter.}

Pengertian pendidikan karakter adalah berbgai usaha yang dilakukan oleh personil sekolah, bahkan yang dilakukan bersama-sama dengan orangtua dan anggota masyarakat untuk membantu anak-anak dan remaja agar menjadi atau memiliki sifat peduli, berpendirian dan bertanggungjawab. ${ }^{2}$ Pemaknaan ini sangat spesifik, bahwa pendidikan karakter suatu pendidikan yang diberikan disekolah agar siswa memiliki jiwa yang responsive terhadap lingkungan, memiliki rasa solidaritas dan loyalitas yang tinggi, bertanggung jawab dalam segala hal. Bahkan lickona mengungkapkan

${ }^{22}$ https;// kompasiana.com/said.samsudin "pendidikan karakter menurut Wiliam dan Schnaps (1999), di akses pada tanggal 2 November 2018 
setidaknya ada tujuh alasan pentingnya pendidikan karakter diberikan di sekolah, anatar laian

a. Merupakan cara terbaik untuk menjamin anak-anak/siswa memeiliki keperibadian yang baik dalam kehidupannya.

b. Merupakan cara untuk meningkatkan prestasi akademik.

c. Sebagaian siswa tidak dapat membentuk karakter dirinya ditempat yang lain.

d. Memepersiapkan siswa untuk menghormati pihak atau orang lain dan dapat hidup dalam masyarakat yang beragam.

e. Berangkat dari akar masalah yang berkaitan dengan problem moral-sosial, seperti ketidak sopanan, ketidak jujuran, kekerasan, pelanggaran seksual dan etos kerja serta (belajar) yang rendah.

f. Memepersiapkan persiapan terbaik untuk menyongsong perilaku di tempat kerja.

g. Mengajarkan nilai-nilai budaya merupakan bagian dari kerja peradaban. ${ }^{3}$

Dari pengertian di atas dapat dipahami, bahwa pendidikan karakter di sekolah sangat penting di terapkan, karena menyangkut pembentukan karakter siswa dalam proses menuju kesempurnaan, kematangan dalam bertindak, berperilaku dan beradab.

\section{Adanya keinginan pemerintah daerah untuk mewujudkan pendidikan religius}

Setiap masyarakat berusaha mendidik dan mengasuh keluarganya menurut cita-cita yang dimilikinya, oleh karena itu cita-cita tersebut berbeda antara satu masyarakat dengan masyarakat yang lain. Religius adalah cara hidup yang sesuai dengan prinsip-prinsip dasar ilahiyah dengan mengacuh pada al-Qur'an dan alHadis. Pendidikan adalah suatu proses yang mempunyai tujuan untuk menjadikan peserta didik memiliki akhlak yang mulia. Setiap proses pendidikan mengandung arah dan tujuan dengan mengacu pada asas dasar peraturan pemerintah, baik secara nasional maupun lokal. Oleh karena itu pendidikan dalam Religius setidaknya mesti memiliki tiga unsur pokok, yaitu: tujuan pendidikan, isi pendidikan dan metode pendidikan.

Tujuan pendidikan secara hakiki berarti membawa kita pada tujuan hidup manusia, sebab pendidikan membawah manusia dalam arah perkembangan moral maupun spiritual. Hal ini selaras dengan isi dari surat keputusan Bupati rejang Lebong berkenaan dengan keinginan pemerintah daerah untuk mewujudkan pendidikan religius.

\footnotetext{
${ }^{3}$ https;//kompasiana.com/said.samsudin "pendidikan karakter menurut Wiliam dan Schnaps (1999), di akses pada tanggal 2 November 2018
} 


\section{Adanya keinginan pemerintah daerah untuk mengatsi kenakalan remaja di sekolah SMA.}

Bukan rahasia lagi, bahwa dewasa ini kenakalan remaja (usia sekolah) meranjak meningkat terlihat dari banyaknya penghuni lapas klas II a Curup Kabupaten rejang Lebong sebagai mana diketahui peningkatan tersebut disebabkan beberapa faktor ${ }^{4}$ :

1. Kurangnya sosialisasi dari orangtua kepada anak mengenai nilai-nilai moral dan social.

2. Contoh perilaku yang ditampilkan orangtua (modeling) di rumah terhadap perlaku dan nilai-nilai anti moral

3. Kurangnya pengawqasan terhadap anak (baik aktivitas pertemanan di sekolah ataupun diluar sekolah)

4. Kurangnya disiplin yang diterapkan orangtua pada anak.

5. Rendahnya kulaitas hubungan orangtua terhadap anak

6. Tingginya konplik dan perlaku agresif yang terjadi dalam lingkungan keluarga.

7. Kemiskinan dan kekerasan dalam lingkungan keluarga.

8. Anak tinggal jauh dari keluarga dan tidak ada pengawqsan dari figure otoritas lain.

9. Adanya saudara kandung atau tiri yang menggunakan obat-obatan terlarang atau melakukan kenakalan remaja.

Setidaknya sepuluh item di atas sebagai pemicu kenakalan remaja di sekolah. Dengan demikian peran orangtua yang sangat penting. Sudah sepantasnya orangtua bertanggung penuh dengan keadaan dan perkembangan anaknya.

Di sisi lain, mahasiswa Institut Agama Islam Negeri (IAIN) Curup banyak berasal dari kalangan siswa SMA di kabupaten Rejang Lebong. Hal ini bisa disebabkan oleh IAIN Curup merupakan Perguruan Tinggi religius satu-satunya yang ada di kabupaten Rejang Lebong khususnya dibidang agama Islam. Yang terdiri dari tiga fakultas dan 17 program studi. Menyikapi, bahwa sebagian besar mahasiswa IAIN Curup juga adalah siswa SMA sederajat yang ada di Kabupaten Rejang Lebong maka sangat diperlukan ada kerjasama antara pihak IAIN dengan sekolah SMA agar input mahasiswa lebih berkualitas dalam penerimaan mahasiswa baru.

Selanjutnya, bahawa tugas pokok dari para Perguruan Tinggi melaksanakan Tridharma Perguruan Tinggi (melakukan pendidikan, penelitian dan pengabdian). Sebagai suatu kewajiban bagi setiap dosen untuk melakukan ketiga unsur tersebut. Oleh karenanya kerja sama antara IAIN Curup terhadap siswa SMA sederajat yang ada di lingkungan Kabupaten Rejang Lebong yang tertuang dalam Mou bebrapa waktu yang lalu merupakan hal yang penting. Tujuannya adalah disamping SMA sederajat sebagai tempat pelaksanaaan praktikum mengajar mahasiswa atau PPL,

${ }^{4}$ https//health.detik.com/ibu-anak-inspired- kid/penyebab kenakalan remaja, diakses pada tanggal 2-11-2018 
juga bertujuan agar IAIN memberi kontribusi bagai siswa SMA dalam membentuk nilai-nilai keberadaban dan tauhid sebagai wujud pembentukan karakter religius siswa.

Disamping itu sebagai implementasi dakwah bagi civitas akademik IAIN Curup. Menurut Hasan Langgulung, bahwa fungsi pendidik:

a. Memberi tauladan yang baik kepada mereka tentang kekuatan iman kepada Allah Swt. Dan berpegang pada ajaran agama dengan sempurna dalam waktu tertentu.

b. Membiasakan mereka menunaikan syariat-syariat agama semenjak kecil sehingga penunaian itu menjadi kebiasaan yang melekat dan mereka melakukannya dengan kemauan sendiri.

c. Menyiapkan suasana agam dan spiritual yang sesuai dengan agama dan dimana mereka berada.

d. Membimbing mereka membaca bacaan-bacaan agama yang berguna dan meikirkan ciptaan-ciptaan Allah.

e. Menggalakan mereka turut serta dalam aktivitas-aktivitas agama.

Hal ini juga didorong oleh realitas sosial. Data kenakalan remaja kabupaten Rejang Lebong menunjukkan semakin hari semakin meningkat. Terlihat dengan adanya data kenakalan remaja yang ada di Kabupaten Rejang Lebong. Misalnya, dari data Lapas kls II a. Kab Rejang Lebong Ada 23 anak narapidana anak-anak dengan berbagai kasus hukum.

\section{Kerjasama Pemerintah Daerah Dan Institusi Pendidikan Tinggi}

Bentuk kerjasama pemerintah daerah sudah banyak diterapkan khususnya dalam dunia pendidikan. Keinginan bersama dari suatu masyarakat dalam mendidik dan memperhatikan perkembangan remaja dewasa ini tidak main-main. Misalkan saja walikota Musi rawas menggagas untuk menjadikan daerah yang religius dengan sebutan "darussalam" adalah kerjasama pemerintah daerah, tokoh agama dan masyarakat kemudian diimplementasikan pada lembaga pendidikan di lingkungan Musi Rawas. Adapun bentuk kebijakan tersebut antara lain:

1. Sekolah mewajibkan siswa berbusana muslim, untuk sekolah non Islam menyesuaikan.

2. Sekolah wajib melaksanakan sholat berjamaan di sekolah khusus sholat zuhur dan asar.

3. Sekolah wajib memberantas buta huruf al-Qur'an bagi peserta didik/siswanya.

4. Sekolah boleh mengembangkan ektrakurikuler khususnya materi keagamaan (tahfiz, tilawah, nasyid dan lain sebagainya.

5. Menggalakkan pengajian pada setiap RT/RW sampai pada tingkat Wali kota.

\footnotetext{
${ }^{5}$ Media catak “ Lubuk Linggau Pos, Pemerintah Daerab membangun SDM berbasis Agama, terbit pada tanggal 24 Januari 2015, hlm. 3
} 
Disisi lain, pendidikan tinggi negeri dan berciri khaskan Islam satu-satunya di Kabupaten Rejang Lebong adalah IAIN Curup. sejak awal dan ketika itu masih berstatus sekolah tinggi, IAIN Curup secara kelembagaan sudah menjalin kerjasama dengan pemerintah daerah dalam berbagai bidang. Bahkan salah satu syarat untuk alih status dari IAIN ke IAIN adalah dukungan Pemerintah Daerah. Ketika IAIN menjadi IAIN kerjasama semakin ditingkatkan. Hal ini dikarenakan IAIN Curup sebagai Perguuruan Tinggi wajib melaksanakan Tri Dharma Perguruan Tinggi, yaitu melaksanakan Pendidikan dan Pengajaran, melakukan Penelitian dan juga Pengabdian kepada masyarakat. Diantara bentuk kerjasama IAIN Curup dan Pemerintah, bahwa IAIN Curup berperan aktif dalam mewujudkan keinginan Bupati Rejang Lebong yang ingin menjadikan Curup sebagai kota idaman yang religius. Beberapa kegiatan yang merupakan kerjasama dengan pemerintah daerah antara lain:

1. Melaksanakan safari jumat

2. Melaksanakan pengajian Kabupaten

3. Melaksanakan KPM perubahan mental dan karakter.

4. Penyuluhan dan pengajian di masyarakat (di bayar oleh pemerintah daerah guru ngaji ditingkat RT/RW)

5. Meningkatkan pendidikan karakter di sekolah

6. Meningkatkan pendidikan religius di sekolah

Kebijakan pemerintah daerah Kabupaten Rejang Lebong untuk menjadikan sekolah yang ada di daerah Rejang Lebong berkarakter dan religius bukan sekedar slogan belaka dan terbukti beberapa sekolah SMA yang ada di Kabupaten Rejang Lebong sudah melaksanakan program tersebut. Sebagai mana yang disampaikan oleh pihak sekolah berikut ini.

a. Wawancara langsung dengan Wakil kurikulum SMA N 2 Kab. Rejang Lebong Program di sekolah dibagi menjadi 2 aspek. ${ }^{6}$

1) Aspek keagamaan

a) Secara seratus persen tentu belum, tetapi beberapa hal sudah dapat dilaksanakan. Misalnya melaksanakan solat zuhur berjamaah, asar berjamaah dan solat ju'mat berjamaah.

b) Kemudian memperingati hari-hari besar religius, selanjutnya kegiatan risma, seperti nasyid, pengajian dan untuk kelas unggul mereka memiliki program unggulan yaitu program tahfiz.

c) SMA N 2 salah satu sekolah yang menyelenggarakan program sekolah full day School tujuannya agar siswa tidak terlalu banyak bermain dan atau memperhatikan HP sehingga mengurangi siswa terkontaminasi dengan

\footnotetext{
${ }^{6}$ Wawancara dengan wakil bidang kurikulum SMA N 2 (RS) Kab Rejang Lebong, pada tanggal 23 agustus 2018
} 
media yang tidak mendidik, karena pada hari sabtu anak-anak tetap dituntut untuk kesekolah karena ada program pengembangan bakat dan minat yang dilaksanakan pada hari sabtu.

d) SMA N 2 merupakan sekolah rujukan,satu satunya di Kabupaten rejang Lebong maksudnya sebagai sekolah percontohan dan ini sudah berjalan pada tahun kedua.

2) Aspek karakter

a) Sedangkan untuk kegiatan karakternya, setiap pagi guru piket berdiri di depan pintu gerbang dan siswa disambut dengan cara bersalaman.

b) Membuang sampah pada tempatnya.

c) Sarapan bersama sarapan pagi gizi seimbang. Dengan cara cuci tangan, makan buah baru mahkan bersama. Kemudian membiasankan senyum, salam sapa, sopan santun yang ditanamkan.

d) Pengelolaan koperasi siswa dengan mempercayai siswa sebagai pengelolanya.

Dari hasil wawancara di atas, baik pola pendidikan keagamaan (religius) maupun karakter secara umum SMA N 2 Kabupaten Rejang Lebong yang merupakan sekolah rujukan sebagai satusatunya sekolah percontohan dan juga sebagai sekolah yang mendapatkan nominasi bersih secara nasional, sudah menunjukkan keunggulan dalam berbagai bidang dan cukup epektif dalam meningkatkan moralitas anak, walaupun ketika ditanya tentang kenakalan siswa seperti penyimbangan seksualitas atau penyalahgunaan obat-obatan terlarang, diakui bahwa siswa seko;ah ini juga pernah terlibat. Lalu konsekuensinya tergantung pada tingkat kategori dilihat dari aspek rendah (misalnya sekedar korban dari temannya setelah diketahui) maka pihak sekolah masih tetap memberikan toleransi artinya belum dikeluarkan dari sekolah, melainkan dinasehati, dibuat surat perjanjian dan dipanggil orangtuanya. Apabila siswa tersebut setelah diteliti ternyata sudah terkategori tingkat pelanggaran berat maka sekolah memberikan hukuman dengan cara mengeluarkan siswa tersebut ${ }^{7}$ Selain SMA N 2 kabupaten Rejang Lebong, peneliti juga melakukan wawancara dengan pihak sekolah SMA N 3, berkenaan dengan realisasi program pemerintah daerah berkenaan dengan pendidikan karakter dan religius. Sebagai mana tertera berikut ini, melalui wawancara secara langsung.

b. Hasil wawancara langsung pada wakil kurikulum SMA N 3

Ada beberapa poin penting yang disampaikan dari SMA N 3 mengenai program pemerintah daerah berkenaan dengan keinginan pemerintah untuk menjadikan ssiswa SMA berkarakter dan religius, berdasarkan informasi

\footnotetext{
7 Wawancara dengan wakil Kurikulum, (Rm) pada tanggal 12 Agustus 2018
} 
wawancara secara eksklusif pada salah seorang guru sekligus menangani kurikulum di sekolah SMA N 3 yang sudah menangani banyak hal tentang perbaikan sekolah ini, justru sangat memperihatinkan, bahwa sekolah belum pernah tahu atau mendengar baik langsung maupun tidak langsung tentang program pemerintah daerah tersebut. Tetapi sekolah SMA N 3 sudah menjalankan program tersebut memang dari pihak sekolah sendiri. Sama halnya dengan SMA N 2, bahwa pihak sekolah SMAN 3 membagi program pada aspek, yaitu agama dan karakter. ${ }^{8}$

1. Aspek agama. Pada aspek agama sekolah memang ekstra dalam menangani masalah keagamaan. Salah satu program yang dilakukan sekolah dengan menanamkan aqidah pada anak, melalui jumat barokah. Kegiatan yang dilakukan adalah :

a) Ceramah/tausiyah setiap jumat, yang dilakukan oleh guru secara bergiliran, seluruh siswa dikumpulkan dilapangan berserta dengan guru-guru dan fokus mendengarkan ceramah.

b) Menghidupkan remaja masjid. Melakukan pengajian, sholat berjamaah dan membaca al-Qur'an secara bergiliran untuk semua siswa.

c) Memantau perkembangan anak setiap hari. karena menurut penuturan bapak wakil kurikulum SMAN 3, bahwa siswa sekolah ini meurpakan sasaran empuk pengkristenisasian, terbukti bahwa anak-anak mereka sudah ada yang dimurtadkan. Adapun factor penyebabnya karena sebagian besar siswa SMAN 3 anak yang tidak siap belajar tetapi disuruh sekolah/belajar. Karena siswa bukan dibentuk dari keluarga yang mampu, melainkan sebagaian besar siswa dari golongan tidak mampu. Berbeda dengan siswa dari SMAN 1 (penegasan wakil kurikulum) memang mereka dari keluarga yang benar-benar siap belajar, dari perekonomia mereka mampu, dari keluarga memeng diperhatikan, sehingga wajar kalau siswanya berkualitas" Kemudian wakil kurikulum juga menagskan, bahwa perjuangan di sekolah kami berat, karena salah satu guru mereka adalah aktivis gereja yang semula adalah seorang muslim, sehingga anak-anak di iming-imingi dengan materi, seperti uang dan makanan agar mereka meninggalkan agam Religius dan masuk agama lain.

d) Usaha sekolah juga dalam rangka perbaikan dan penguatan aqidah dan perbaikan moralitas anak, yaitu dengan cara membuat buku saku dan dibagikan pada siswa secara gratis. Isi dari buku tersebut berkenaan dengan cerita jenaka tetapi penguatan aqidah, perintah sholat, ngaji, dan lain sebagainya.

2. Aspek karakter siswa. Karakter yang dibangun oleh pihak sekolah, adalah kegiatan pemerhatian tentang tindakan yang menyimpang. Misalnya sekolah melaksanakan beberapa kegiatan sebagai berikut:

${ }^{8}$ Wawancara dengan wakil Kurikulum SMAN 3 ( Bapak Rs), pada tanggal 5 Agustus 2018 
a) Mencerdaskan siswa melalui ceramah umum, seperti bersikap baik dan benar pada lingkungan, baik lingkungan sekolah maupun masyarakat.

b) Penjelasan bahaya narkoba serta pengaruhnya. Baik pada diri sendiri maupun orang lain.

c) Mengantisipasi jangan sampai siswa melakukan tindakan seperti tawuran, anarki, penyalahgunaan pergaulan bebas, penyimpangan seksual dan lain sebagainya.

d) Kemudian sama dengan SMA yang lain, bahwa SMAN 3 ini memberikan sanksi terhadap siswa yang melanggar aturan sekolah. Misalnya terlibat narkoba, kalau ternyata siswa adalah korban, maka diadakan pembinaan dan belum dikeluarkan, yaitu melalui konseling remaja, baik penanaman nilai keagamaan maupun nilai-nilai moralitas sesuai dengan perundang-undangan yang berlaku dinegeri ini.

e) Berkenaan dengan antisipasai tentang adanya beberapa tindakan yang tidak diinginkan (karakter siswa yang tidak terpuji, wakil kurikulum SMAN 3 yang berpendidikan S1 dengan gelar S.Pd) dan sudah menggeluti bidang kurikulum selama 2 tahun mengemukakan, bahwa dengan jumlah siswa lebih kurang 600 orang dan jumlah guru sebanyak 64 orang baik guru tetap maupun honor, bahwa jam 7.00 dia sudah hadir di sekolah dan memperhatikan semua kegiatan dan perkembangan anak setiap harinya. Oleh karena itu apabila ada isu atau kabar burung yang menerangkan tentang perilaku siswanya yang kurang bekenan, maka pihak sekolah mengadakan penyelidikan secara berkesinambungan dengan membentuk tim pencari fakta guna mencari kebenaran informasi tersebut ${ }^{9}$

Berdasarkan hasil wawancara dengan pihak sekolah, dari beberapa sekolah yang dijadikan subjek dalam penelitian ini memberikan pemahaman, bahwa setiap sekolah memang tidak sama permasalahan yang di hadapi masing-masing guru, baik sebagai pelaksana dan juga regulasi terhadap kebijakan sekolah, maupun yang melekat pada personil seorang guru sebagai figuran dimana dia dituntut berperan ganda, sebagai pendidik di sekolah dan juga pengayom dan pelindung anak didiknya di masyarakat. Tanggungjawab yang melekat pada setiap guru tidaklah ringan, apa lagi ketika dihadapkan dengan kondisi anak serba kekurangan, baik dari segi sepiritual, artinya kurang mendapatkan perhatian dari kedua orangtuanya lantaran sibuk bekerja dan lain sebagainya, bahkan juga segi material, artinya secara ekonomi tidak mendukung anak untuk sekolah, sehingga dalam menghadapi kondisi yang serba sulit, maka guru dituntut berperan ganda, yaitu sebagai pendidik dan juga sebagai penyelamat siswanya agar tetap bisa sekolah dengan mencarikan sumber beasiswa.

${ }_{99}$ Wawancara pada WK kurikulum SMAN 3, pada tanggal 16 Oktober 2018. 
Berdasarkan kondisi siswa sebagaian besar di Rejang Lebong, sangat wajar kalu masih ada siswa yang tidak sanggup untuk melanjutkan sekolah atau siswa yangberkemampuan dari segi sepiritual tetapi tidak mampu dari segi material. Hal ini sangat lah dimungkinkan, karena memang Kabupaten Rejang Lebong masyarakat sebagian besar sebagai petani kopi dan palawija. Rata-rata perkapita mereka hasil kopi hanya 1 tahun sedangkan palawija sekedar melengkapi kebutuhan hidup sehari-hari, walaupun tidak semuanya. Sehingga dapat dimungkinkan jika masih ada masyarakat yang tidak sanggup untuk membiayai anaknya untuk sekolah. Tarap hidup masyarakat masih menengah ke bawah bukan ke atas. Jika dibandingkan dengan kabupaten yang ada sekitar, misanya Lubuk Linggau, sebagai penghasil karet, walaupun murah harga karet namun mereka rutin penghasilannya setiap hari. sehingga kebutuhan hidup dapat berjalan dengan lancer. Berbeda dengan hal tahunan seperti kopi, walauopun harganya mahal tetapi kalau panen satu kali dalam satu tahun tentu sangat menyulitkan, karena untuk kebutuhan sehar-hari masyarakat susah untuk terpenuhi, biaya makan, sekolah anak, kebutuhan yang lain yang tidak terduga misalnya, tentulah menyulitkan.

Tanggungjawab para guru dan dalam mengemban tuga sebagai seorang pendidik juga akan dipengaruhi oleh kondisi orangtua/wali siswa. Kebutuhan siswa yang banyak, sementara perekonomian orangtua tidak mendukung, sehingga siswa tidak bisa berbuat banyak. Dalam kondisi seperti tersebut dimungkinkan jika siswa menghalalkan segala cara dlam memenuhi kebutuhan sekolahnya. Atau siswa malas untuk sekolah, jadi kondisi tersebut memungkinkan siswa akan melakukan tindakan diluar kebiasaannya, mencuri, merampok dan lain sebagainya. Atau malas sekolah putus sekolah, gelandangan misalnya, lari ke sisi gelap kehidupan (siswa narkoba, tawuran, berkelahi, pelecehan seksual dan lain sebagainya).

\section{Kendala Yang Dihadapi Pemerintah Daerah Dan IAIN Curup Dalam Menerapkan Pendidikan Karakter}

Hambatan atau kendala adalah sebuah persoalan, di mana adanya ketidak sesuaian atara keinginan dan harapan dengan kenyataan yang terjadi. Istilah hambatan identik dengan masalah yang di hadapi. Pengertian masalah adalah adanya ketidak sesuaian antara teori dan kenyataan. ${ }^{10}$ Setiap aktifitas manusia, baik peroangan maupun kelompok ketika menginginkan keberhasilan dan kesuksesan pasti mengalami permasalahan. Jika besar harapan atau keinginan tersebut, biasanya besar pula masalah yang dihadapi dan sebaliknya, jika kecil program atau kegiatan yang

\footnotetext{
10 Wk Kurikulum SMAN 3 (Bapak Rs) pada tanggal 26 Oktober 2018
} 
ingin di capai tersebut dmungkinkan kecil juga masalah yang di hdapi. Hanya saja sebesar atau sekecil apapun masalah tersebut tergantung yang menghadapinya, dalam menyelesaikannya. Kalu bijak dalam mengatasi masalah tersebut maka dimungkinkan maslah tersebut dapat diselesaikan dengan baik. Tetapi tidak jarang pula masalah yang kecil bisa menjadi besar bahkan bisa menimbulkan masalah yang baru. Oleh kerenanya bijaklah dalam mengatasi masalah.

Dalam pengimplemtasian nilai-nilai karakter dan religius di sekolah SMA (siswa) juga tentu mengalami maslah. Secara keseluruhan berdasarkan wawancara dengan guru seputar permasalahan yang dihadapi guru dalam melaksanakan pendidikan karakter dan religius. Dalam pengungkapan masalah yang dihadapi, sengaja peneliti menyorotinya pada dua aspek yaitu internal sekolah dan ekternal sekolah, sebagai mana diungkapkan oleh WK Kurikulum berikut ini.'

1. Faktor Internal SMAN 3 Kabupaten Rejang Lebong

a. Internal sekolah. Peneliti mencoba mengungkap masalah yang dihadapi sekolah secara lembaga dan kelembagaan. Berdasarkan wawancara dengan waka kurikulum SMAN 3, mengungkapkan kendala yang dihadapi secara lembaga dan kelembagaan, anatar lain:

1. Belum semua guru memiliki misi untuk memajukan siswa dalm bidang karakter dan religius secara serius, karena sebagaian besar guru bukan dari pendidikan agama. Sehingga siswa diharapkan lebh unggul pada aspek keilmuan sain dan teknologi tapi bukan untuk spiritual dan keagamaan. Apa lagi mata pelajaran agama tidak termasuk standar kelulusan dalam ujian nasional.

2. Akibat dari kurangnya misi dari semua guru, berakibat pula pada kurangnya minat siswa untuk mendalami agama dan karakter.

3. Padatnya jam pelajaran rutinitas umum, sehingga jam pelajaran agama tergeser menjadi pelajaran yang dikesampingkan, karena tidak di jadikan pelajaran sebagai standar kelulusan, maka kurang serius dalam memahami dan mempelajarinya.

4. Kurangnya tenaga pengajar khusus pendidikan agama Islam, sehingga guru yang ada tidak maksimal. Sementara untuk menambah guru honor terkendala oleh keuangan, karena tidak ada alokasi dana yang tersedia.

5. Sarana dan prasaran pendidikan agama Islam masih belum maksimal, seperti al-Qur'an, buku-buku bacaan yang bersifat praktis tentang muatan pendidikan Islam belum tersedia dengan baik. Pamphlet, brosur, spanduk atau slogan yang bernuansakan keIslaman belum tersedia.

6. Pendidikan karakter belum bisa diterapkan dengan maksimal, karena guru yang mengajar karakter biasanya guru Pkn, sehingga semua permasalahan yang menyangkut kenakalan siswa biasanya diserahkan pada guru Pkn.

7. Belum diterapkannnya konseling dengan baik. Masih ada istilah bahwa guru konseling hanya menangani anak bermasalah. 
8. Masih ada pola fikir diantara guru, bahwa mengungkap kenakalan siswa adalah aib sekolah. Oleh karena itu cukup sekolah yang tau, kendatipun masalah tersebut dianggap melanggar norma agama atau hukum.

b. Internal siswa. Ketika di tanya tentang hambatan dari dalam diri siswa, secara keseluruhan adalah ${ }^{11}$ :

1. Siswa berlatarbelakang bukan dari sekolah agama, bahkan mereka mengenal solat dan baca tulis al-Qur'an ketika di SMA.

2. Kurangnya motivasi dan perhatian oratua terhadap anaknya, sehingga anak belum dibiasakan untuk melakukan mengaji, sholat dan lain sebagainya.

3. Orantua siswa belum berupaya untuk memajukan anaknya di bidang agama, missal TPA/MDA, les ngaji dan lain sebagainya.

4. Sebagian besar orantua adalah petani, sibuk (pergi pagi pulang malam) sehingga anak-anak lepas control.

5. Siswa kami tidak siap belajar sementara harus sekolah.

6. Ketrbatasan ekonomi siswa, sehingga sulit untuk memenuhi pasilitas yang dibutuhkan terutama berkenaan dengan pelajaran pendidikan agama Islam.

7. Siswa lebih tertarik menonton media elektronik yang ada di HP (video, film) daripada mendengarkan ceramah agama di sekolah.

Dari beberapa jawaban dari pihak sekolah SMAN 3 atas responden yang disampaikan peneliti melalui wawancara langsung, dapat diketahui bahwa hambatan internal yang dihadapi sekolah dalam pengimplementasian nilai-nilai karakter dan religis di sekolah tersebut secara tidak langsung adalah sebagai penghambat tujuan yang ingin dicapai sekolah, yaitu menciptakan alumni sekolah yang berkualitas secara umum dan siswa diharapkan dapat mengendalikan diri dari tindakan yang melawan norma agma dan sosial masyarakat atau pemerintahan. Inilah yang dikatakan oleh salah seorang tokoh pendidikan Islam ${ }^{12}$, bahwa pendidikan bertujuan menciptakan manusia yang taat kepada Allah dan juga pemerintah, tidak menjadi beban bangsa mampu mengembangkan potensi yang dimiliki dan senantiasa berakhlak mulia.

Artinya sekolah berusaha membimbing siswa dengan maksimal untuk menjadikan generasi muda (siswa) lebih maju dan kreatif dalam pengembangan potensi yang ada. Tidak stagnan setelah tamat sekolah SMA siswa merasa puas dengan ilmu yang dimiliki. Begitu juga terhadap kompetensi yang dimilkinya. Dengan berbagai hambatan tersebut tidak menjadikan pihak sekolah serta merta menerima dan pasrah dengan keadaan, tetapi lebih kepada pemacuan diri siswa untuk maju. Motivasi dari guru sangat berharga dan lebih bermanfaat. Karena terkadang sisiwa lebh mudah mendengar nasehat atau masukan dari gurunya daripada oranagtua mereka. Oleh karenanya kerjsama pihak sekolah dan orangtua sangat diharapkan

11 Wawancara WK Kurikulum SMAN 3, tgl. 23 Oktober 2018

12 Nazaruddin Umar, Pendidikan Islam dan dimensi Spiritualitas, Bandung, Bina Press, hln. 32 
demi kemajuan anaknya. Paling tidak ada beberapa kerjasama orangtua dengan sekolah sehubungan dengan perkembangan anaknya:1) kerjasama dalam pengawasan. Orangtua bertanggungjawab penuh atas perkembangan anknya, karena sekolah dibatasi oleh ruang dan waktu, sedangkan kedua orangtua memeiliki tanggungjawab penuh. 2) Kemudian orangtua berkewajiban memenuhi kebutuhan anaknya, baik material maupun sepiritual. Tanpa danya dorongan dan perhatian dari kedua orangtuanya mana mungkin anak dapat melaksanakan pendidikan dengan maksimal. 3) kerjasama dalam hal pengawasan fisik dan psikis anaknya. 4) pengawasan pada proses pembelajaran, misalnya orangtua hendaknya memperhatikan kegiatan belajar anak, tugas anak di sekolah, hasil belajar anak, dan ada support yang baik terhadap anaknya. 5) kerjasama dalam mengatasi masalah yang berkenaan dengan hukum. Baik hukum agama maupun undang-undang dalam Negara ini.

2. Faktor Eksternal SMAN 3 Kabupaten Rejang Lebong

Berikut ini akan diuraikan faktor ekternal. Ketika di wawancarai tentang factor apa saja yang dianggap penghambat dalam penerapan model pendidikan karakter dan religius ini, berikut hasil wawancara dengan WK kurikulum SMAN 3 Kabupaten rejang Lebong. diungkapkannya sebagai berikut:

1. Kuranngnya perhatian dan pengawasan dari lembaga yang menaungi sekolah kami, khususnya perhatian terhadap pendidikan Islam.

2. Kurangnya penyuluhan dan pembinaan dari lembaga yang menaungi, misalnya penyuluhan tentang bahaya narkoba, bahaya LGBT

3. Sulitnya mendapatkan sarana belajar seperti buku-buku tentang sholat, alQur'an perangkar sholat dan wudu'

4. Sulitnya komunikasi dengan wali murid, ketika diundang rapat evaluasi, walimurid sulit untuk datang, dengan berbagai alasan.

5. Belum ada kesepakatan kerjasama secara menyeluruh terhadap beberapa instansi (mou) sehingga siswa kurang wawqsan.

6. Pembiayaan yang relative sedikit, sehingga untuk mengadakan kegiatan positif, seperti PHBI wisata religi dan lain sebagainya tidak dapat dilaksanakan. Sehingga sekolah kami belum bisa bermutu, karena yang bermutu pasti mahal.

Dari faktor tersebut diketahui, bahwa kerjasama dengan lembaga lain sangat penting sebagai salah satu upaya untuk menjadikan siswa bermutu dan berkualitas, sebagai mana beberapa siswa SMA yang viral di sosmed, mampu membuat kendaraan (mobil), menciptakan elektronik tepat guna, penggunaan bahan limba bekas dan lain sebagainya semua itu dikarenakan adanya pelatihan secara intensif dan pendanaan yang memadai. Di Kabupaten Rejang Lebong siswa SMA juga bisa melakukan hal yang sama termasuk misalnya ahli dibidang pendidikan Islam, seperti tahfiz, ahli kaligrafi, seni-seni Islam yang lain termasuk nasyid ${ }^{13}$.

${ }^{13}$ M.Quraish Shihab, 2005, Wawasan al-Qur'an, Bandung, Mizan, hlm. 385 
Begitu juga dengan SMAN 2 Kabupaten Rejang Lebong, berdasarkan hasil wawancara langsung dengan WK kurikulum.

1. Faktor Internal SMAN 2 Kabupaten Rejang Lebong

a. Faktor penghambat yang terjadi dari dalam lingkungan sekolah (lembaga dan kelembagaan). SMAN 2 termasuk sekolah vavorit karena siswa yang masuk di sekolah ini, bukan siswa yang tidak lagi diterima di sekolah lain, melainkan calon siswa di jarring dengan ketat, baik administrasi maupun kompetensi keilmuan siswa, misalnya administrasi, syarat mutlak calon siswa dilakukan tes urine apakah terindikasi Napza atau tidak, surat keterangan kelakuan baik dari kepolisian. Kemudian dari diri calon sisiwa memiliki standar NEM tertentu dan juga untuk siswa beragama Islam diadakan tes baca al-Qur'an dan bacaan sholat. Hal tersebut wajar dilakukan karena memang SMAN 2 tersebut merupakan sekolah rujukan atau sekolah percontohan, ditambah lagi sebagai sekolah nomor tiga secara nasional dari aspek sekolah sehat.

b. Faktor internal. Hambatan yang terjadi dari dalam diri siswa berdasarkan hasil wawancara dengan WK kurikulum juga mengungkapkan, bahwa diantara hambatan dalam pengimplementasian nilai-nilai pendidikan karakter dan religius siswa, antara lain:

1. Ada rasa jenuh dalam diri siswa ketika belajar. Karena siswa sitem bejarnya fullday school sehingga siswa merasa terkuras dalam berfikir, akibat dari itu kurang termotivasi dengan maksimal untuk mengikuti pelajaran agama Islam dengan maksimal.

2. Siswa kurang termotivasi untuk belajar pendidikan agama Islam karena pelajaran agama Islam tidak dijadikan mata pelajaran sebagai salah satu syarat ujian nasional.

3. Kurangnya motivasi dari dalam diri siswa, karena kurangnya motivasi dari kedua orangtua.

4. Faktor ekonomi. Siswa yang ekonomi keluarganya pas-pasan, berakibat tidak dapat memenuhi kebutuhan sekolahnya, misalkan membeli buku dan lain sebaginya. Karena banyaknya kebutuhan yang membutuhkan biaya, seperti les di sekolah dan membeli buku paket pelajaran yang cukup mahal.

5. Lingkungan sekitar yang kurang mendukung. Lingkungan dimaksud baik dalam keluarga maupun sekolah.

2. Faktor Eksternal SMAN 2 Kabupaten Rejang Lebong

a. Faktor eksternal sekolah. Sebagai manan telah diceritakan sebelumnya, bahwa SMA Negri 2 Kabupaten Rejang Lebong tidak sama dengan SMA yang lain. Karena SMA N 2 sudah termasuk sekolah yang menjadi vavorit, artinya kelengkapan dan epektifitas belajar mengajar sudah berjalan dengan baik. Oleh karena itu secara rinci kendala yang dihadapi SMAN 2:

1. lingkungan sekolah yang kurang mendukung, di mana sekolah bertempat tinggal dilingkungan jalan lintas, dari segi keamanan kurang menguntungkan 
karena siswa keluar masuk mengalami kesulitan, kemudian situasi belajar sedikit terganggu.

2. Belum maksimal hubungan antar sekolah-sekolah vavorit (Mou). Karena siswa lebih termotivasi dan menimbah pengalaman dari sekolah lain dan dapat mencontoh kemajuan sekolah lain.

3. Belum maksimal perhatian pemerintah daerah terhadap sekolah kami, seharusnya sebagai pemerhati dunia pendidikan sudah sepantasnya memberikan dukungan dan motivasi secara maksimal, berikanlah reword ketika sekolah kami berprestasi dalam kegiatan even nasional bahkan internasional, sehingga ada rasa loyalitas pemerintah daerah terhadap dunia pendidikan di daerah.

4. Masih ditemukan orangtua (wali siswa) yang belum maksimal dalam menjalin kerja sama dengan sekolah dalam memajukan anaknya. Terlihat ketika ada undangan agar datang kesekolah, tetapi masih ada yang tidak mempedulikan undangan tersebut.

b. Faktor Eksternal siwa. Hambatan yang sering terjadi menurut wak Kurikulum dan juga guru dari luar diri siswa ${ }^{14}$, antara lain:

1. Alat elektronik (HP). Siswa disibukkan dengan HP sehingga siswa lebih senang dan termotivasi melihat hiburan, film, video di you tube, dari pada belajar dan belajar.

2. Kurangnya motivasi dari orantua siswa untuk mempelajari pendidikan agama Islam, terlihat dari anak-anak mereka bisa membaca al-Qur'an dan melaksanakan sholat dengan baik sebagian besar melalui bimbingan guru di sekolah.

3. Pelajaran pendidikan agama Islam tidak dijadikan standar kelulusan, sehingga siswa menganggap sepeleh, karena belajar pendidikan Islam semata sebagai khazanah keilmuan semata.

4. Siswa sulit membagi waktu karena jadual pelajaran siswa full. Dari jam 7.0016.00 .

5. Banyaknya kegiatan siswa, seperti latihan pidato, paskib, palang merah dan lain-lain, sehingga menyulitkan siswa untuk fokus dalam pendidikan agama Islam.

Dari hasil wawancara dengan guru dan siswa di atas dapat diketahui, bahwa kendala yang dihadapi bervariasi. Namun ada bebera kesamaan dari responden tersebut, misalnya pengaruh alat komunikasi (HP), kemudian pengaruh lingkungan yang kurang mendukung, baik dari keluarga maupun masyarakat sekitar. Oleh karena itu sudah seharusnya para pemerhati meluangkan waktu untuk memberikan perhatian, bantuan dan juha motivasi terhadap siswa-siswa SMAN yang ada di Kabupaten Rejang Lebong dalam melaksakan proses pendidikan. Karena siswa

\footnotetext{
${ }^{14}$ Wawancara dengan guru dan juga siswa, pada tanggal 13 Oktober 2018
} 
tersebut sebagai cikal bakal anggota masyarakat, bahkan calon praktisi seperti guru, karyawan, ilmuan, cendikiawan, dan juga calon pemimpin bangsa ini nantinya. Dunia pendidikan identik dengan generasi pembangunan, merupakan tugas bersama dari masyarakat untuk menjadikan siswa menjadi manusia yang berguna, bertanggungjawab dan memiliki akhlak mulia. Bukan sebaliknya, apabila satu sama lain kurang memberikan perhatian, maka tidak menutup kemungkinan siswa tersebut justru menjadi beban bangsa, generasi yang memilki masa depan yang suram, mabukmabukan, narkoba, berbuat kerusuhan, membuat kegaduhan dalam masyarakat dan memiliki akhlak tercela.

Sebagai kelengkapan dari data ini, penelti mengungkapkan hasil responden atas pertanyaan yang disampaikan beberapa waktu yang lalu dari SMAN 4 Kabupaten Rejang Lebong. Sama halnya dengan cara pengungkapan responden di atas, bahwa SMAN 4 juga akan dilakukan pertanyaan seputar hambatan yang dihadapi pihak sekolah dalam pengimplementasian nilai-nilai religius dan karakter. Berbeda dengan SMA sebelumnya, bahwa WK kurikulum SMAN 4 bapak St yang sudah menabat bidang kurikulum pada tahun kedua dan sebagai salah seorang aktivis gereja juga sebagai tugas tambahan, mengungkapkanbeberapa hambatan.

1. Faktor Ekternal SMAN 4 Kabuaten Rejang Lebong

a. Faktor Internal sekolah. Merupakan impian dari setiap sekolah untuk tetap memajukan siswanya dapat unggul dalam setiap aspek. Begitu juga dengan sekolah SMAN 4 yang dahulu terkenal dengan nama Sekolah Berstandar Internasional (SBI), namun seiring dengan pergeseran waktu dan lain hal SBI tidak lagi dijadikan model pembelajaran dan kurikulum di sekolah ini. Menurut wk kurikulum ${ }^{15}$, hambatan dalam penerapan pendidikan karakter dan religius, antara lain:

1. Minim guru agama yang berkibat juga terbatasnya jam pelajaran pendidikan agama Islam.

2. Kesulitan membagi waktu, karena kegiatan siswa kita padat, ekschool siswa banyak, ada paskib, PMI, latihan berbahasa Inggeris, vocal. Sedangkan untuk pengembangan pada pendidikan Islam, seperti nasyid, tahfiz sebagai mana di terapkan di sekolah SMA yang lain, untuk SMAN 4 tidak melakukan itu, paling kalu hari jumat siswa berbusana muslim, jumat barokah sesekali belajar ngaji di sekolah (jawaban wk kurikulum).

3. Ketika ditanya tentang pengawasan dari pemerintah daerah terhadap kegiatan di sekolah, bapak yang notabene sebagai guru Pkn ini juga mengatakan, sampai sekarang belum ada pengawasan dari instansi yang menaungi.

\footnotetext{
15 Wawancra dengan wk Kurikulum SMAN 4 (bapak St) pada tanggal 21 Oktober 2018.
} 
4. Jarangnya penyuluhan, baik agama maupun hukum nasional. Misalnya dari phak kepolisian melakukan penyuluhan narkoba misalnya, atau kejahatan sosial seperti pelegehan, LGBT misalnya.

5. Belum maksimalnya kerjasama $(\mathrm{MoU})$ sebagai salah satu usaha memajukan mutu dan kualitas sekolah/siswa. Untuk mencocokan antara pernyataan wk kurikulum dengan jawaban siswa, maka penelitipun mewawancarai beberapa orang siswa. Tentang hambatan dalam penerapan pendidikan karakter dan religius, dikemukan oleh siswa, "bahwa dahulu sekolah kami cukup bagus, ketika dijadikan sekolah SBI, namun akhir-akhir ini sekolah kami biasa-biasa saja, tidak ada yang menonjol dan dahulu ayuk-ayuk tingkat kami memiliki banyak prestasi di sekolah, ada nasyid, ada kaligrafi, ada lomba busana muslim, lomba tilawa, namun sekarang tidak lagi" (celoteh siswa yang masih polos) ${ }^{16}$

\section{Faktor Internal SMAN 4 Kabupaten Rejang Lebong}

Hambatan yang dihadapi sekolah tidak hanya berasal dari ektra sekolah, tetapi juga justru yang paling sering dan banyak dari internal sekolah. Oleh karena itu peneliti akan mewawancarai guru dan siswa dalam rangka mengungkap permasalahan yang ada. Secara rinci jawaban guru menjawab ${ }^{17}$ sebagai berikut:

1. Kesibukan siswa cukup padat, sehingga kami tidak terlalu membebani dengan berbagai macam kegiatan ekschool. Walaupun sekolah kami sekolah seperti sekolah yang lain yaitu enam hari sekolah, namun siswa kami banyak melakukan kegiatan di luar sekolah.

2. Pendidikan karakter sudah diterapkan walaupun belum maksimal, hanya saja, boleh jadi sekolah menerapkan tetapi tidak sama dengan lingkungan keluarga dan masyarakat, contoh kita ajarkan siswa bersikap sopan santun, terkadang orangtua mereka memberikan contoh yang tidak bagus, baik sikap maupun omongan.

3. Adanya pengaruh tontonan di HP, sehingga siswa terkadang melakukan pelanggaran, baik agama maupun hukum perundang-undangan di negeri ini. Siswa mudah mengakses video terlarang, kekerasan, seksual, LGBT dan lain sebagainya yang tidak pantas untuk di tonton.

4. Kurangnya kerja sama antara wali siswa dengan pihak sekolah, contoh ketika diminta untuk datang kesekolah berkenaan dengan anaknya, baik hal positif maupun negative orangtua masih ada yang tidak mengindahkan atau tidak mau hadir. Sepenuhnya menyerahkan dengan pihak sekolah.

5. Belum ada kesadaran anak dalam mengamalkan ajaran Islam, karena kurang dukungan dari orangtua mereka dan juga latarbelakang sekolah mereka bukan dari sekolah agama.

\footnotetext{
16 Wawancara dengan siswa kelas II IPA, IPS (ris, ina, roy, jes) pada tanggal 19 Oktober 2018

17 Wawancara dengan guru (ibu tr) pada tanggal 7 Oktober 2018.
} 
6. Sarana pendidikan agama Islam sangat terbatas. Misalnya buku-buku tentang pendidikan agam Islam tuntunan sholat praktis, yang sifatnya simple dan muda di baca, siswa bosan kalu sekedar mendengar cerama atau nasehat dari guru, lebih tertarik melihat video atau gambar-gambar ${ }^{18}$

7. Penyajian materi tidak terlalu menarik, khususnya materi pendiidkan agama Islam. Guru dalam penyampaian materi cerita melulu, sehingga kami bosan, terkadang ada unsure keterpaksaan mengikuti pelajaran tersebut. Tidak ada perkembangan dari hari kehari ceritanya seputar itu-itu saja ${ }^{19}$

8. Muatan dalam ajaran Islam banyak yang bertentangan dengan kehidupan sehari-hari kami sebagai siswa, sementara banyak kegiatan-kegiatan kami yang menuntut peran yang sedikit berseberangan dengan ajaran Islam. Misalnya perempuan dilarang membuka aurat dan aurat perempuan semuanya kecuali telapak tangan dan muka. Lalu disekolah kami ada latihan drumband, dengan model pakaiannya pendek dan seksi. Kemudian dilarang menunda-nunda sholat, sedangkan kami pulang sekolah jam 1.30 atau jam 14.00, kadang di sekolah kami tidak sholat dan sampai kerumah kita sudah capek dan tidur, akhirnya tidak sholat zuhur ${ }^{20}$

Dari beberapa jawaban guru dan siswa atas pertanyaan peneliti berkenaan dengan hambatan dari dalam sekolah/siswa itu sendiri bermacam-macam faktor. Permasalahan tersebut bila diamati memang bertentengan dengan beberapa aturan yang seharusnya tidak terjadi atau sebagai penghambat suksesnya tujuan pendidikan nasional itu sendiri. Oleh karena itu seharusnya para pemerhati pendidikan sudah selayaknya memberikan dukungan moral dan spiritual dan menggalakan model pendiidkan karakter dan religius. Bentuk dan model pengembangan pembelajaran dapat dilakukan dengan cara memperbaharui media pembelajaran dan muatan materi/bahan ajar sehingga tidak terkesan statis atau stagnan. Melainkan dapat menyesuaikan perkembangan dunia pendidikan dan perkembangan zaman. Pendidikan bertarap hidup orang banyak, artinya : 1) memajukan kesejahteraan umat manusia. 2) mencerdaskan pola fikir dan gaya hidup umat manusia. 3) mengatasi mentalitas dan mencerdaskan pola fikir umat manusia. 4) menanamkan karakter dan nilai-nilai keberagamaan pada siswa. ${ }^{21}$ secara keseluruhan bahwa pendidikan bertujuan menyempurnakan kompetensi manusia dalam berbagai aspek. Oleh karena itu memerlukan berbagai faktor sebagai pendukung kelengkapan dalam mencapai tujuan tersebut. Begitu juga dengan kegiatan belajar mengajar siswa SMAN yang ada di lingkungan Kabupaten Rejang Lebong pada umumnya dan SMAN 2, 3 dan SMAN 4 yang dijadikan subjek dalam penelitian ini.

Pemerintah daerah berkewajiban untuk membangun daerah masing-masing

\footnotetext{
18 Wawancara dengan siswa (ur, sin, ker) pada tanggal 9 Oktober 2018

${ }^{19}$ Wawancara dengan siswa (ef, nur, lin) pada tanggal 29 Oktober 2018.

20 Wawancara dengan siswa (rin, sin dan ef), pada tanggal 29 Oktober 2018

${ }^{21}$ Hasan Langgulung, 2012, Manusia dan Pendidiakn tinjauan Filsafat Pendidikan, Jakarta azzikra. Hlm. 76
} 
termasuk memperhatikan sumber daya manusianya. Begitu juga Pemda Kabupaten Rejang Lebong, berfikir dan berkeinginan untuk mewujudkan tujuan pendidikan secara nasional dengan memperhatikan dan memperbaiki kualitas pendidikan daerah tertentu. Meminimalisisr kejahatan remaja juga merupakan diantara tugas pemerintah daerah bersama-sama dengan praktisi pendidikan. Menjaga keamanan dan stabilitas daerah merupakan salah satu cara mewujudkan pembagunan daerah tersebut. Apa lagi dewasa ini kasus provinsi Bengkulu secara nasional terkenal sebagai daerah yang kurang aman, seringnya tindakan criminal, seperti penodongan, jambrat, pencurian yang tidak segan-segan menghilangkan nyawa orang sebagai mana yang terjadi di kecamatan Bermani ulu (kepala Curup) dan sekitarnya. Kemudian kasus pemerkosaan anak dibawah umur yang terjadi pada siswi SMP yang diperkosa 12 orang pemuda juga merenggut nyawanya dan orangtuanya sampai sekarang masih trauma ${ }^{22}$. Dan yang tidak kalah memperihatinkan maraknya penyakit HIV dan AIDS di provinsi Bengkulu meningkat dengan pesat ( tahun 2018 sebanyak 1000 orang penderita HIV dan AIDS $^{23}$ sudah seharusnya ada kerjasama dan perhatian secara serius antara pemerintah daerah dan praktisi pendidikan dalam menangani berbagai kasus kejahatan di atas.

\section{Penutup}

Berdasarkan hasil penelitian di lapangan dan sesuai dengan hasil wawancara dari beberapa pertanyaan yang disampaikan kepada subjek penelitian, baik sekolah menengah atas (SMA) 1, 2, 3 dan 4 tentang implementasi kebijakan Pemda untuk mewujudkan pendidikan karakter dan religius di sekolah, dapat disimpulkan; Pertama sebagian besar sekolah SMA sudah berusaha menerapkan pendidikan tersebut dengan baik dan maksimal, terlihat dari beberapa perubahan yang dilakukan sekolah dalam rangka mengantisispasi agar siswa tidak terlalu banyak menyia-nyiakan waktu di rumah terutama main HP. Diadakan solat zuhur dan asar dan juga jumat di sekolah. Kedua adanya penambahan kegiatan ekstra kurikuler seperti tahfiz, nasyid, risma dan pengajian di sekolah. Ketiga siswa disuruh menenkuni bakat dan minat sesuai dengan keinginan dan pilihannya. Misalnya drumband, paskibra, vocal, tilawah. Keempat setiap jumat diadakan acara jumat barokah (ceramah/pidato), kemudian adanya penyuluhan keagamaan dan hukum.

Adapun bentuk kerjasama pemerintah daerah dan IAIN Curup dalam mengatasi kenakalan remaja yakni; pertama melalui program rutinitas Praktik Pengalaman Lapangan (PPL) dan Kuliah Pengabdian Masyarakat (KPM) dosen IAIN Curup melakukan safari jum'at, kemudian mengadakan guru ngaji di setiap RT/RW dan diberi honor oleh Pemda. Kedua melalui kegiatan akademik kampus. Kemudian kegiatan lomba, seperti HUT dewan racana IAIN Curup, mengadakan lomba keagamaan, seperti azan, tilawah, kaligrafi, pidato bahasa Arab dan Inggeris dan lain

\footnotetext{
22 Data Kriminalitas di klas II A LAPAS Curup. Kab. Rejang Lebong.

${ }^{23}$ Data RSUD Curup tahun 2018
} 
sebagainya. Atau kegiatan yang digagas khusus mahasiswa, misalnya seminar tentang kenakalan remaja, pemuda kreatif dan ber karya dan lain sebagainya. Ketiga melalui organisasi mahasiswa, yang juga melibatkan siswa SMA, seperti Pergerakan Mahasiswa Islam Indonesia, Himpunan Mahasiswa Islam (HMI), KAMMI. IMM.

Hambatan yang dihadapi sekolah dalam pengimplemtasian nilai-nilai pendidikan karakter dan religius di sekolah berdasarkan hasil wawancara langsung, sebagai mana di jelaskan di atas, Pertama dari faktor ekternal, yaitu belum maksimal perhatian pemerintah dalam memberikan perhatian dan dukungan terhadap pada lembaga pendidikan khususnya SMA yang ada di Kabupaten Rejang Lebong khusus pendidikan agama Islam, Kedua keterbatasan sarana dan prasana pendidikan agama Islam, seperti: al-Qur'an, Iqro' mukena atau buku-buku tuntunan sholat. Ketiga masih ada orangtua yang kurang memberikan support dan perhatian kepada anaknya dalam keluarga, terutama mengarahkan anaknya untuk mempelajari pendidikan agama Islam. Selain itu, kurangnya bimbingan orangtua dalam menerapkan nilai-nilai pendidikan Islam dalam keluarga, seperti sholat, mengajarkan etika dan adab yang baik, hal tersebut dikarekan kesibukan orangtua dan orangtua mempercayakan sepenuhnya kepada sekolah untuk mendidik anak mereka.

\section{Bibliografy}

Badan Pelaksanaan Desa Binaan IAIN Curup.2011.Panduan pelaksanaan Desa binaan IAIN Curup.

Burhanuddin.2003.Pedoman Komite Madrasah.Jakarta:Departemen Agama RI, Direktorat Kelembagaan Agama Islam.

------2004.Politik Kebijakan di Indonesia peran tokoh-tokoh Religius dalam penyusunan Undang-undang nomor 2 tahun 1989. Jakarta:INIS Laeden.

Donelly,James H, James Gibson John,M.Ivans civics.1987.Fundamentals of Menegement.Busines publication.

Duhou,Ibtisam Abu.2002.School Based Manajement pengantar A.Malik Fadjar.Jakarta:Logos wacana Ilmu dan pemikiran,

HM.Arifin.2003.Ilmu Pendidikan Religius Tinjanan Teoritis dan Praktis Berdasarkan interdisipliner.Jakarta:Bumi Aksara.

Idrus HA. Kamus Besar Bahasa Indonesia.Surabaya:Bintang Usaha

Kamal, Muhammad, Isya.1994.Manajemen Pendidikan Religius.Jakarta:Fika hati aneka.

Koentjoroningrat.2007. Antropologi Budaya.Jakarta:Renika Cipta.

Langgulung,Hasan.2010.Manusia dan Pendidikan Suatu Analisa Psikologis Filsafat dan Pendidikan.Jakarta:Renika Cipta.

Malik Fajar.1998.Madrasah dan Tantangan Modernitas. Bandung: Mizan.

Mangku negara, Anwar.2000.Manajemen Sumber daya manusia.Bandung:Remaja Rosda karya. 
156 | Belajea: Jurnal Pendidikan Islam, Vol. 2, No. 02, 2019

M.Quraish Shihab. 2005. Wawasan al-Qur'an Tafsir Maudhu'I atas berbagai permasalaban ummat, Bandung Mizan

Mulyasa.2002.Manajemen Berbasis Sekolah Konsep strategi dan implementasi. Bandung :PT. Remaja Rosdakarya.

Nanang,Fatah.1996.Landasan Mnenjemen Pendidikan.Bandung:Remaja Rosda Karya.

Natta,Abudin.2001.Paradigma Pendidikan Religius.PT.Gramedia Widia sarana Indonesia.

Nurcholish.2003.Manajemen Berbasis Sekolah.PT.Gramedia Widis sarana Indonesia.

Rachim,Husni.2001. Arah baru Pendidikan Religius. Jakarta:Logos wacana Ilmu.

-----2003.Corak lembaga Pendidikan Religius di Indonesia.makalah Seminar Manajemen Pendidikan.

Saleh,Abdul Rachman.2004.Madrasah dan Pendidikan Anak Bangsa, Visi Misi dan Aksi.Jakarta:Raja Grafindo.

Sidi, Indra Jati.2000.Kebijakan Penyelenggaraan Otonomi Daerah Bidang Pendidikan. Bandung: PPs UPI.

------2003, Pedoman Manajemen berbasis Madrasah, Departemen Agama RI: Direktorat Jendral Kelembagaan Agama Islam.

Siharuddin MS.2004.Hubungan Kepemimpinan dengan Kualitas Pengelolaan Madrasab pada MTsN 2 Palembang (Tesis). Palembang : PPs IAIN Raden Fatah

Sihombing U.2001.Konsep dan Pengembangan Pendidikan Berbasis Masyarakat Reformasi Pendidikan dalam Kontek Otonomi Daerah. Jakarta: Depdiknas Dirjen Dikdasmen.

Sirozi, Paradigma Pengembangan Madrasah Masa Depan (makalah seminar) seminar pengembangan dan peningkatan Kualitas Madrasah di Sumatra Selatan Kantor Wilayah Departemen Agama bekerjasama dengan pusat pengembangan Madrasah (PPM)Sumatra Selatan, 14 mei 2003. 